\title{
Section VII: Civilians Directly Participating in Hostilities
}

\author{
Rule 71 \\ Civilians directly participating in hostilities lose their protection from attack \\ for such time as they do so.
}

\section{Commentary}

1. This Rule is based on Article 51(3) of AP/I. ${ }^{1}$ Non-contracting parties to AP/I support the customary principle on which that Article is based. ${ }^{2}$

2. The rule on direct participation in hostilities has been addressed in the ICRC Interpretive Guidance on the Notion of Direct Participation in Hostilities under International Humanitarian Law. ${ }^{3}$ The content of the Interpretive Guidance has been contested by many commentators.

3. The loss of civilian immunity from attack due to direct participation in hostilities is limited to "such time" as the participation lasts. However, the precise duration of the timeframe involved is a matter of some controversy (particularly in "revolving door" situations).

4. When a person is a member of an organized armed group, he/she is targetable at all times.

5. The Group of Experts agreed that civilians are subject to attack when they take a direct and continuous part in armed conflict, and they cannot invoke protection from attack during temporary lulls in this participation. ${ }^{4}$ Accordingly, the

\footnotetext{
${ }^{1}$ See chapter "Section I: Outer Space", fn. 13.

${ }^{2}$ US DoD Law of War Manual, see chapter "Section II: Cyber Operations", fn. 4 Section 5.9.1.2.

${ }^{3}$ International Committee of the Red Cross, ICRC Interpretive Guidance on the Notion of Direct Participation in Hostilities under International Humanitarian Law (2009).

${ }^{4}$ US DoD Law of War Manual, see chapter "Section II: Cyber Operations", fn. 4, at 5.8 .4 (discussing the duration for which a civilian in DPH is subject to attack),; HCJ 769/02 Public Committee Against Torture v. Government of Israel para. 27, 38-40 [2006] (Isr.).
} 
timeframe for the loss of protection due to DPH would be analogous to that of their military counterparts, as the assigned function of operating RPAs or UMSs would be considered sufficient evidence of a continuous/ongoing pattern of DPH subjecting the civilian to deliberate attack.

6. The operating of RPAs or UMSs by civilians may result in loss of protection, but this will depend on the activity in which they are engaged.

7. In view of the severe consequences of DPH the decision on whether an activity qualifies as DPH should be based on reasonably reliable information.

\section{Rule 72}

Private military contractors (PMC) retain their civilian protection as long as they are not incorporated in the armed forces-including militia or volunteer corps-and do not directly participate in hostilities.

\section{Commentary}

1. This Rule is based on Article 51(3) of AP/I. Non-contracting parties to AP/I support the customary principle on which that Article is based. ${ }^{5}$

2. Private military contractors may be individually hired or, alternatively, may be employees of private military corporations.

3. The status of PMC is examined in detail in the Montreux document of 2008, which points out pertinent legal obligations and good practices applicable to States using PMCs in military operations. ${ }^{6}$ Although the Montreux document is not legally binding, it reflects the policy views of participating States.

4. Provided the following activities do not constitute direct participation in hostilities, they may be undertaken by PMCs without losing their civilian protection:
a. Guarding of store houses;
b. Escorting civilian dignitaries;
c. Undertaking construction works;
d. Engaging in food services;
e. Engineering;
f. Providing technical support;
g. Carrying out instruction tasks; and
h. Other non-combat activities.

\section{Rule 73}

If persons who are authorized to accompany the armed forces without actually being members thereof-such as supply contractors-fall into the

\footnotetext{
${ }^{5}$ US DoD Law of War Manual, Section 5.9.1.2.

${ }^{6}$ See The Montreux Document On pertinent international legal obligations and good practices for States related to operations of private military and security companies during armed conflict (2008).
} 


\section{power of the enemy during an international armed conflict, they are entitled to the status of prisoners of war in accordance with the third Geneva Convention of 1949 Article 4(A)(4).}

\section{Commentary}

1. This Rule, which is based on GC/III, is today declaratory of customary international law applicable in international armed conflict. ${ }^{7}$

2. In accordance with GC/III, persons authorized to accompany the armed forces may also include:

a. Civilian members of military aircraft crews;

b. War correspondents;

c. Members of labour units or of services responsible for the welfare of the armed forces;

3. The armed forces that the persons concerned are authorized to accompany must provide them with an identity card, as indicated in GC/III. Loss of an identity card does not deprive the person concerned of POW status.

4. There were divergent views within the Group of Experts about the status of persons who accompany the armed forces but participate directly in hostilities. One view was that by participating directly in hostilities, they retain POW status but may be criminally liable under domestic law for any act of hostility. By contrast, the other view was that they may lose their entitlement to POW status in certain situations in as much as they are assimilated to unlawful/unprivileged combatants. Another view, also reflected in the U.S DoD Law of War Manual, is that they are entitled to POW status, and generally cannot be held criminally liable for authorized support activities, including such support activities constituting direct participation in hostilities.

5. In any event, an enemy person who is captured shall initially be treated as a POW until his/her status has been determined. If the person claims POW rights e.g., by producing an identity card indicating that he or she is a person authorized to accompany the armed forces, but circumstances indicate that the person's status is dubious, the case should be heard according to GC/III Article 5(2).

6. Article 5 of GC/III (second paragraph) provides that "[s]hould any doubt arise as to whether persons, having committed a belligerent act and having fallen into the hands of the enemy, belong to any of the categories enumerated in Article 4, such persons shall enjoy the protection of the present Convention until such time as their status has been determined by a competent tribunal".

7. States bound by AP/I are obligated to observe Article 45(1), whereby "[a] person who takes part in hostilities and falls into the power of an adverse Party shall be presumed to be a prisoner of war, and therefore shall be protected by the Third Convention, if he claims the status of prisoner of war, or if he appears to be entitled to such status, or if the Party on which he depends claims such status on

\footnotetext{
${ }^{7}$ GC/III, see chapter "Section I: Outer Space", fn. 19, Article 4 A (4).
} 
his behalf by notification to the detaining Power or to the Protecting Power. Should any doubt arise as to whether any such person is entitled to the status of prisoner of war, he shall continue to have such status and, therefore, to be protected by the Third Convention and this Protocol until such time as his status has been determined by a competent tribunal".

8. This Rule is of course limited to International Armed Conflicts. It is not applicable to Non-International Armed Conflicts.

\section{Rule 74}

Persons who are authorized to accompany the armed forces without actually being members thereof, but participate directly in hostilities, are subject to attack by the enemy.

\section{Commentary}

1. The consensus view of the Group of Experts was that LOAC does not prohibit DPH by civilians, but only exposes them to certain consequences as a result of DPH. Accordingly, DPH itself cannot be properly characterized as a breach of LOAC or as a war crime. Nonetheless, DPH may result in a violation of applicable domestic criminal laws, either as a result of the DPH itself (e.g., in U.S. law the crime of providing material support to terrorism), or as a result of its consequences (e.g., an attempted or completed violation of domestic criminal prohibitions against murder, arson, aggravated assault, etc.).

Open Access This chapter is licensed under the terms of the Creative Commons Attribution 4.0 International License (http://creativecommons.org/licenses/by/4.0/), which permits use, sharing, adaptation, distribution and reproduction in any medium or format, as long as you give appropriate credit to the original author(s) and the source, provide a link to the Creative Commons licence and indicate if changes were made.

The images or other third party material in this chapter are included in the chapter's Creative Commons licence, unless indicated otherwise in a credit line to the material. If material is not included in the chapter's Creative Commons licence and your intended use is not permitted by statutory regulation or exceeds the permitted use, you will need to obtain permission directly from the copyright holder.

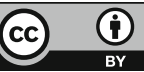

